\title{
REVIEW
}

\section{Fish and oil in the Lofoten-Barents Sea system: synoptic review of the effect of oil spills on fish populations}

\author{
Dag Ø. Hjermann ${ }^{1}{ }^{\text {, Arne Melsom }}{ }^{2}$, Gjert E. Dingsør ${ }^{1}$, Joël M. Durant ${ }^{1}$, \\ Anne Maria Eikeset ${ }^{1}$, Lars Petter Røed ${ }^{2,3}$, Geir Ottersen ${ }^{4,5}$, Geir Storvik ${ }^{1,6}$, \\ Nils Chr. Stenseth ${ }^{1,7, *}$ \\ ${ }^{1}$ Centre for Ecological and Evolutionary Synthesis (CEES), Department of Biology, University of Oslo, PO Box 1066 Blindern, \\ 0316 Oslo, Norway \\ ${ }^{2}$ Norwegian Meteorological Institute, PO Box 43 Blindern, 0313 Oslo, Norway \\ ${ }^{3}$ Department of Geosciences, Section Meteorology and Oceanography, University of Oslo, PO Box 1022 Blindern, \\ 0315 Oslo, Norway \\ ${ }^{4}$ Institute of Marine Research, Gaustadalléen 21, 0349 Oslo, Norway \\ ${ }^{5}$ Bjerknes Centre for Climate Research/GEOS, University of Bergen, Allégaten 55, 5007 Bergen, Norway \\ ${ }^{6}$ Department of Mathematics, University of Oslo, PO Box 1053 Blindern, 0316 Oslo, Norway \\ ${ }^{7}$ Institute of Marine Research, Flødevigen Marine Research Station, 4817 His, Norway
}

\begin{abstract}
The Lofoten-Barents Sea area, which contains some of the most valuable fish stocks of the Atlantic Ocean, is being considered for offshore oil production. We review the effects of a hypothetical oil spill on fishes in this area, with a focus on effects on the egg and larval stage of the 3 dominating fish stocks: NE Arctic cod Gadus morhua, Barents Sea capelin Mallotus villosus, and Norwegian spring-spawning herring Clupea harengus. In particular, we emphasise that the longterm population impact of an oil spill depends on ecological and oceanographic factors, some of which have been poorly explored. Among these are (1) effects of the physical state of the ocean, especially mesoscale circulation features, on the advection of oil and fish larvae, (2) effects of the spatial distribution of spawners, (3) effects of harvesting on stock structure and length of the spawning season, (4) effects of natural mortality and species interactions subsequent to an oil spill, and (5) chronic sublethal effects from persistent oil residues.
\end{abstract}

KEY WORDS: Advection $\cdot$ Fishes $\cdot$ Pollution $\cdot$ Petroleum $\cdot$ Vulnerability

\section{INTRODUCTION}

Although fish eggs and larvae may suffer mortality through oil spills, there are few reported cases in which oil spills have conclusively had a significant impact on fish stocks (IPIECA 1997). However, this does not mean that fish stocks cannot be significantly affected by oil spills. Most data on large oil spills derives from temperate and subtropical environments, where biological productivity and oil degradation rates are high, ecosystems relatively complex, and fish stocks often spawn over a longer period of the year or even year-round. A significant proportion of the unexploited oil reserves (approx. $25 \%$; see USGS 2000) are, however, found in the polar regions, and oil companies are presently turning towards these regions to develop new oil fields. In these areas physical and biological oil degradation is likely to be slower than in more temper- 
ate regions, due to low temperatures (Garrett et al. 2003, Brakstad et al. 2004). Moreover, polar ecosystems are fairly simple (Hamre 1994, Hillebrand 2004) and thus possibly more vulnerable to changes in the abundance of the few key species (Paine 1980). One example is that the collapse of the Barents Sea capelin stock in the 1980s significantly affected several trophic levels including the capelin's prey, zooplankton (Dalpadado et al. 2001), predators such as cod (Hjermann et al. 2004a) and harp seals (Haug \& Nilssen 1995), and alternative prey of its predators such as shrimp (Worm \& Myers 2003). Perhaps most importantly, fish stocks such as cod and herring are close to their climatic limits in these habitats, and due to these environmental constraints they tend to have short, intensive spawning seasons and localised spawning areas. As a result, their eggs and larvae-the life stages most susceptible to oil exposure-may be relatively concentrated along a narrow advection route. These stocks are among the economically and

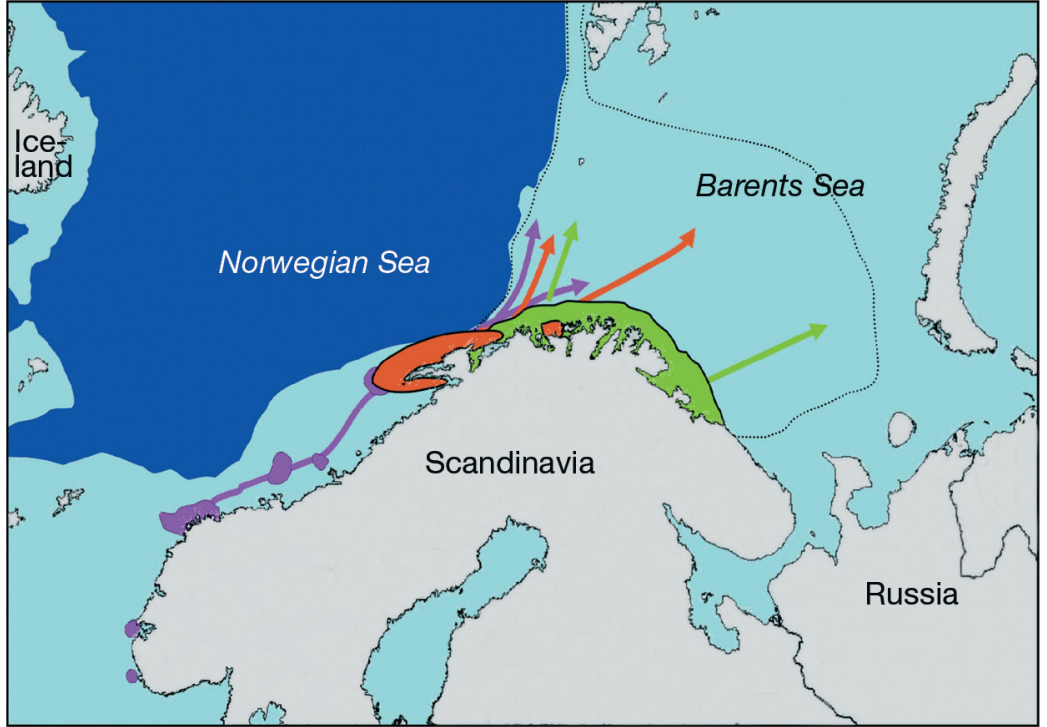

Fig. 1. Lofoten-Barents Sea ecological system with spawning locations and advection routes of eggs and larvae of 3 fish stocks; red: North-east Arctic cod; purple: Norwegian spring-spawning herring; green: capelin (Aglen et al. 2005). Dotted line: maximum extension of the 3 species in the Barents Sea in the first summer following spawning. Light blue: continental shelf $(<250 \mathrm{~m})$; dark blue: deep sea. Larvae and eggs drift passively with the Norwegian Coastal Current (NCC), which runs northwards to the Barents Sea at depths down to $150 \mathrm{~m}$. Further offshore and parallel to it runs the Norwegian Atlantic Current (NAC), a branch of which enters the Barents Sea (cf. Figs. 4 \& 5) ecologically most important fish stocks of the Norwegian and Barents Seas. For more than a millennium, this ecosystem (Fig. 1) has been one of the main food chambers for Europe and together with farmed salmon is the main reason why Norway is the world's third largest exporter of fishes, measured by export value. Norway is also the world's third largest exporter of oil. Exploitation of oil and gas will shortly begin in the Lofoten-Barents Sea area (later denoted LBS; see also Fig. 1), with a gas project (Snøhvit) starting production in 2007, and a nearby oil field (Goliat) to be developed soon. In 2006, it was decided that some of the most controversial areas from a fisheries viewpoint (Aglen et al. 2005) will not be opened for oil exploration until 2010 (Anonymous 2006). However, these areas are also those that are most likely to contain large oil and gas reserves (Anonymous 2006) and their opening will continue to be advocated by the oil industry. In addition, a substantial number of tankers sail along the Norwegian coast, carrying Siberian oil from Russian oil terminals. Risk analyses indicate that Russian export traffic constitutes a higher risk for oil accidents than LBS oil production (Blom-Jensen \& Dervo 2003), especially as new oil terminals are being built on the coast of NW Russia. It has been estimated that this traffic may increase strongly, from 12 million metric t of oil in 2004 (almost 1 tanker $\mathrm{d}^{-1}$ ) to 50 to 150 million metric $t$ in the next decade (Bam- bulyak \& Frantzen 2005). Although the issues of this review are also relevant for tanker spills, we have concentrated on spills from oil installations such as drilling platforms. However, much of the data we review stem from ship accidents.

Herein, we review available information on the impact of possible oil spills in the LBS on 3 fish stocks of major economic importance: the North-east Arctic (NEA) cod, the Barents Sea (BS) capelin, and the Norwegian spring-spawning (NSS) herring (Hamre 1994). The most important spawning grounds of the former 2 stocks are inside the LBS; the latter spawns mainly south of LBS but its larvae are advected into the LBS with the Norwegian Coastal Current (NCC; Fig. 1). In addition, the 3 stocks interact strongly with each other through predator-prey relationships (Bogstad et al. 2000, Hamre 2003, Hjermann et al. 2004a,b, 2007).

In Norway, an environmental impact assessment (EIA) has to be performed before a new area is opened to oil explorations. Part of such an EIA is an assessment of the potential impact of an oil spill. The EIA for oil development in the LBS region was prepared in 2003 (Anonymous 2003), and included a report on possible effects of accidental oil spills on life in the water column (Johansen et al. 2003). With this report as a starting point, we review some factors that affect the impact of an oil spill on fishes in the LBS area. Rather 
than providing a comprehensive review of the vast literature on the toxicological effects of oil, we wish to emphasise some oceanographic and ecological aspects (Fig. 2) that are often considered only superficially in EIAs of oil spills, and which need to be better understood in order to obtain a clear picture of the consequences of oil exploitation on the marine resources in this region (Fig. 3).

\section{ENVIRONMENTAL IMPACT ASSESSMENT (EIA)}

The oil spill section of the EIAs conducted before opening oil exploration fields includes the development of possible oil trajectories and concentrations of
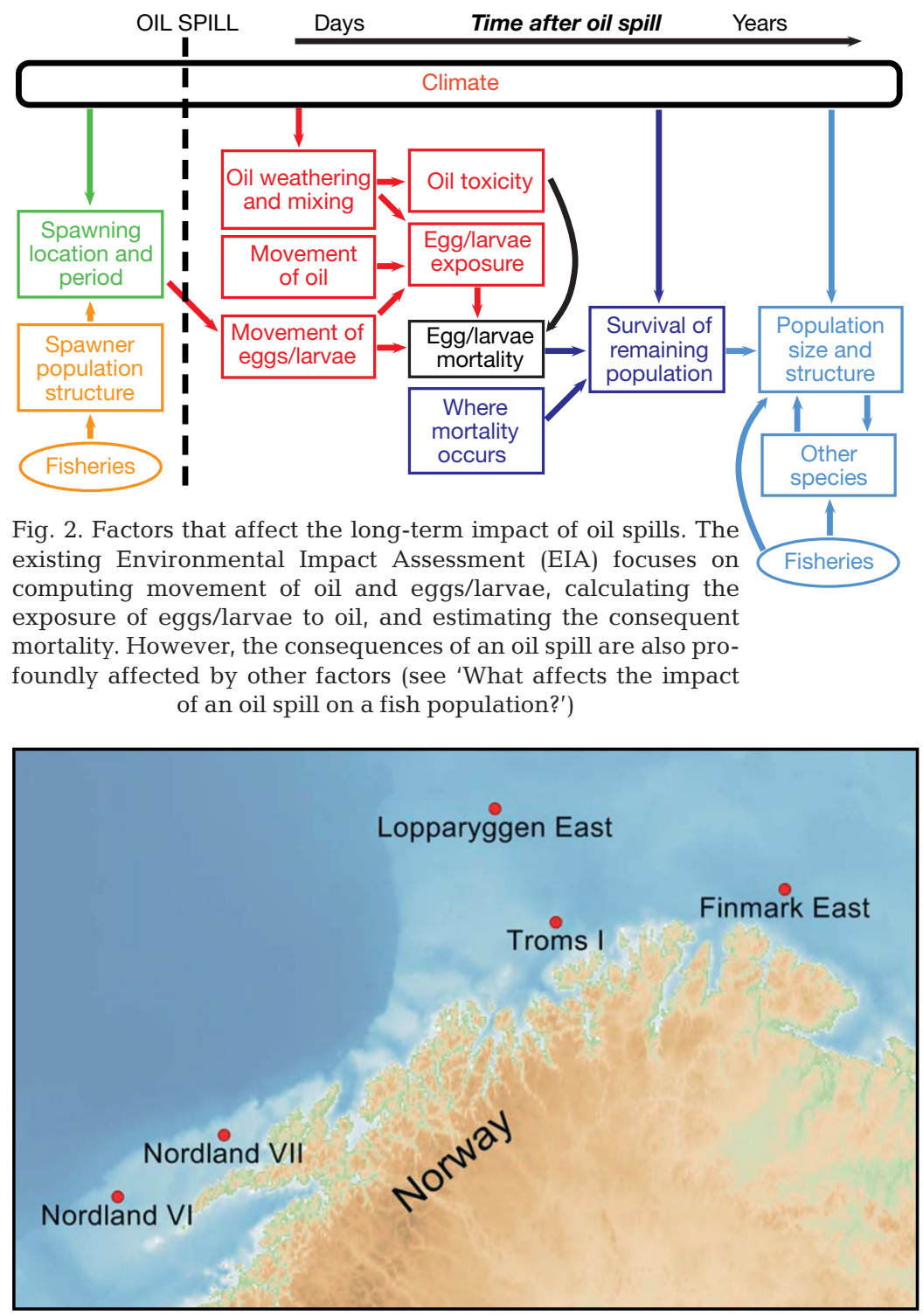

Fig. 3. Oil spill sites used in the simulations of the ULB 7-c spill (Johansen et al. 2003) oil in the water column which, combined with distribution maps of sensitive organisms, is used as a basis for assessing likely ecological impact scenarios. Regions that may be affected by oil pollution are determined by simulated trajectories and weathering of the oil, and usually defined as regions where the probability of an impact from an accidental spill exceeds 5\%. Traditionally, drift trajectories have been computed using an empirical relation between surface winds and the ocean current with which the oil spill is advected (Martinsen 1982). In more recent work, the drift trajectories have been computed from the flow fields of ocean circulation models (Martinsen et al. 1994), taking the full 3-dimensionality of the flow field and hydrology into account (Wettre et al. 2001). Due to the steady expansion of available computer resources, such simulations are now performed with a grid mesh that resolves features such as filaments and eddies. In Norwegian waters, this requires a grid mesh with a resolution of $\leq 5 \mathrm{~km}$. Such a simulation was used for production of drift trajectories in the most extensive examination yet of potential oil spills on the ecology of the LBS region (Johansen et al. 2003).

The drift trajectories are used to simulate drift of both hydrocarbons and fish eggs/larvae, and thereby calculate the exposure of eggs or larvae to hydrocarbons (Johansen et al. 2003). This can then be combined with results from laboratory experiments on the toxicological effects of hydrocarbons to calculate the proportion of the stock that is subject to exposure above some set level. However, several aspects are often disregarded. Firstly, the ecosystem is often viewed in a static way; for instance, it is frequently assumed that the proportion of fish spawning at each spawning location is the same between years, while in reality, this varies substantially. The variation between spawning locations may be caused both by climate (prevailing oceanographic conditions) as well as by the age/size structure of the spawning stock. In cod and herring, which spawn in the coastal current, spawning results in a 'train' of larvae, whose length depends on the spawning time (which varies for biological reasons) and whose route depends on weather conditions. Secondly, it is assumed that all larvae are of equal 
'worth', i.e. that, in the absence of an oil spill, all larvae have an equal chance of survival to fishable size or maturity. However, natural mortality after the larval stage varies substantially both spatially and among years (Ciannelli et al. 2007). Spatial variation is important since an oil spill kills larvae in a specific area. Thus, the impact of a spill on a population will vary, depending on whether the larvae killed were those that would otherwise have had the best chance of reaching fishable size, or whether they were destined to have been transported to an area in which they would have a very low chance of survival. Year-to-year variation in natural survival - which may depend on the state of the ecosystem (abundance of prey, predators, and competitors) - will affect the population's long-term response to oil spill mortality. Finally, we will briefly consider the possibilities of chronic effects of those oil components with long persistence times. Such chronic effects are largely disregarded in the present EIA.

\section{THE LOFOTEN-BARENTS SEA PELAGIC ECOSYSTEM}

\section{Oceanography}

The LBS region consists of the Barents Sea, an open arcto-boreal shelf-sea with an average depth of about $230 \mathrm{~m}$ (Zenkevitch 1963), and the narrow continental shelf along the Norwegian coast down to Lofoten (Fig. 1). The ocean circulation is dominated by the NCC and the Norwegian Atlantic Current (NAC) (Helland-Hansen \& Nansen 1909, Sætre \& Mork 1981, Orvik \& Niiler 2002). The NCC is associated with low-saline coastal water masses. These water masses originate in the Skagerrak and are the result of mixing with freshwater-primarily from rivers discharging into the Baltic Sea, but also into the North Sea from the UK, continental Europe and Scandinavia (Albretsen \& Røed 2006). The NCC passes the southern tip of Norway as it exits from the Skagerrak, and continues along the Norwegian coastal shelf to the Barents Sea. The NAC on the other hand is characterised by water masses of Atlantic origin that flow into the Nordic Seas across the Iceland-Faeroe Ridge and through the Faeroe-Shetland Channel (Østerhus \& Hansen 2000). This inflow is easily recognisable in satellite images (Fig. 4) as a warm-water mass intruding into the Nordic Seas as far north and east as the Barents Sea. As shown in Fig. 4, the inflow is separated by 2 fronts, an easterly front separating it from the NCC, and a westerly front separating it from the polar water masses on the broad Greenland shelf and eastwards. At the entrance to the Barents Sea the NAC divides into 2 branches (Fig. 4), one entering the Barents Sea, and one continuing northwards towards Spitsbergen (Svalbard). Other major characteristics of the ocean circulation in the area are the presence of strong tides and (not least) many mesoscale structures such as filaments, meanders and eddies. Eddies may diverge from the front and influence circulation and hence residence time. Such mesoscale features on scales of 5 to $10 \mathrm{~km}$ are prominent in the Barents Sea (Fig. 5). Note, for instance, the strong current filament or jet-like structure along the Norwegian coast present in both the satellite image (Fig. 5a) and the model forecast in Fig. 5 and how, in general, the dark areas in the satellite image correspond to the areas of strong currents in the model forecast. This reflects the fact that areas of strong currents are areas of strong vertical mixing which tends to reduce the backscatter signal to the satellite. Due to the relatively warm Atlantic water masses of the NAC, sea temperatures in the LBS area are higher than in other regions at similar latitudes. As a result, the southern part of the Barents Sea stays ice-free even in the most severe winters. Year-to-year variability in temperature south of the oceanic Polar

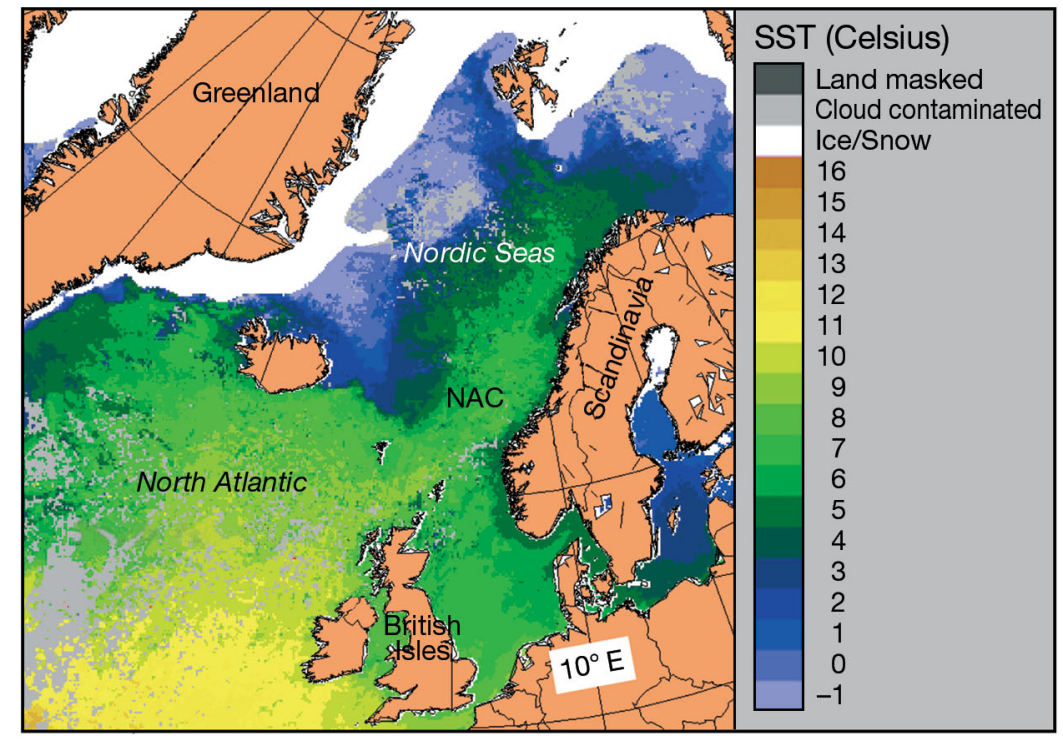

Fig. 4. Sea surface temperature (SST) and sea-ice extent in the northern North Atlantic and Nordic Seas Ocean and Sea Ice Satellite Application (OSI-SAF) product (http://saf.met.no); 7 day satellite imagery composite, centered on April 11, 2004. White: sea ice; gray: cloud masked (contaminated) areas. Latitudelongitude grid on land masses at $10^{\circ}$ intervals. NAC: warm-water tongue of Norwegian Atlantic Current 
front is strongly influenced by the inflow of Atlantic water (Loeng 1991, Ingvaldsen et al. 2003). This variability appears to be mainly wind-driven and hence linked to the North Atlantic Oscillation (NAO) (Hurrell et al. 2003). The correlation between the NAO and the inflow and temperature of the Barents Sea varies greatly with time, being most pronounced early in the last century and over the last 3 to 4 decades (Dickson et al. 2000, Ottersen et al. 2001).

\section{Ecology of the focal fish stocks: NEA cod, NSS herring and BS capelin}

These fish stocks all spawn along the Norwegian coast in winter to spring (Fig. 1). The NSS herring have the southernmost spawning distribution, with spawning sites spread from around $58^{\circ}$ to $69^{\circ} \mathrm{N}$, but especially between $62^{\circ}$ and $64^{\circ} \mathrm{N}$ (Aglen et al. 2005). They spawn on the bottom, and their larvae drift towards the Barents Sea with the NCC current. The herring stay in the Barents Sea until they have grown to a size of $20 \mathrm{~cm}$ (typically at the age of $3 \mathrm{yr}$ ) and then migrate to the Norwegian Sea, where they remain for the rest of their lifespan. Spawning NEA cod are distributed further north, with spawning sites at $62^{\circ}$ to $71^{\circ} \mathrm{N}$, but with the spawning sites at Lofoten and the Røst bank (around $68^{\circ} \mathrm{N}$ ) being the most important (Aglen et al. 2005). Cod spawn pelagically, and their eggs hatch into larvae as they drift northwards. The cod juveniles reach the Barents Sea in summer, and then shift from a pelagic to a demersal life style in September to October; they remain in the Barents Sea for the rest of their life cycle except for spawning migrations after maturation at an age of 6 to $8 \mathrm{yr}$. Of the 3 species, BS capelin spawn furthest north (north of $70^{\circ} \mathrm{N}$ ), close to the coast on the southern fringe of the Barents Sea, at depths of 10 to $60 \mathrm{~m}$. They spawn on sandy/gravel bottoms, attaching their eggs to gravel on the bottom. The eggs hatch after 3 to $8 \mathrm{wk}$ and the larvae migrate upwards to the upper water layers, in which they are advected northward into the Barents Sea during summer and autumn (Gjøsæter 1998, Aglen et al. 2005).

\section{Economic and ecological importance of the fish stocks}

Economically, the NEA cod is by far the most important of the 3 stocks. Dried cod originating from the cod's spawning grounds at Lofoten has been one of Norway's largest export items for about 1000 yr. At present, most of the other large stocks of Atlantic cod have collapsed, with the NEA stock the largest remaining, accounting for about $50 \%$ of the total annual cod catch (2004: ca. 600000 metric $t$ of NEA cod including unreported landings; ICES 2005). Second in economic importance is the world's largest herring stock, the NSS herring, which supports an annual fishery of up to 1.2 million metric $t$ (one of the largest fisheries in the North Atlantic). The BS capelin stock is also the world's largest stock of this species (catch up to 2.9 million
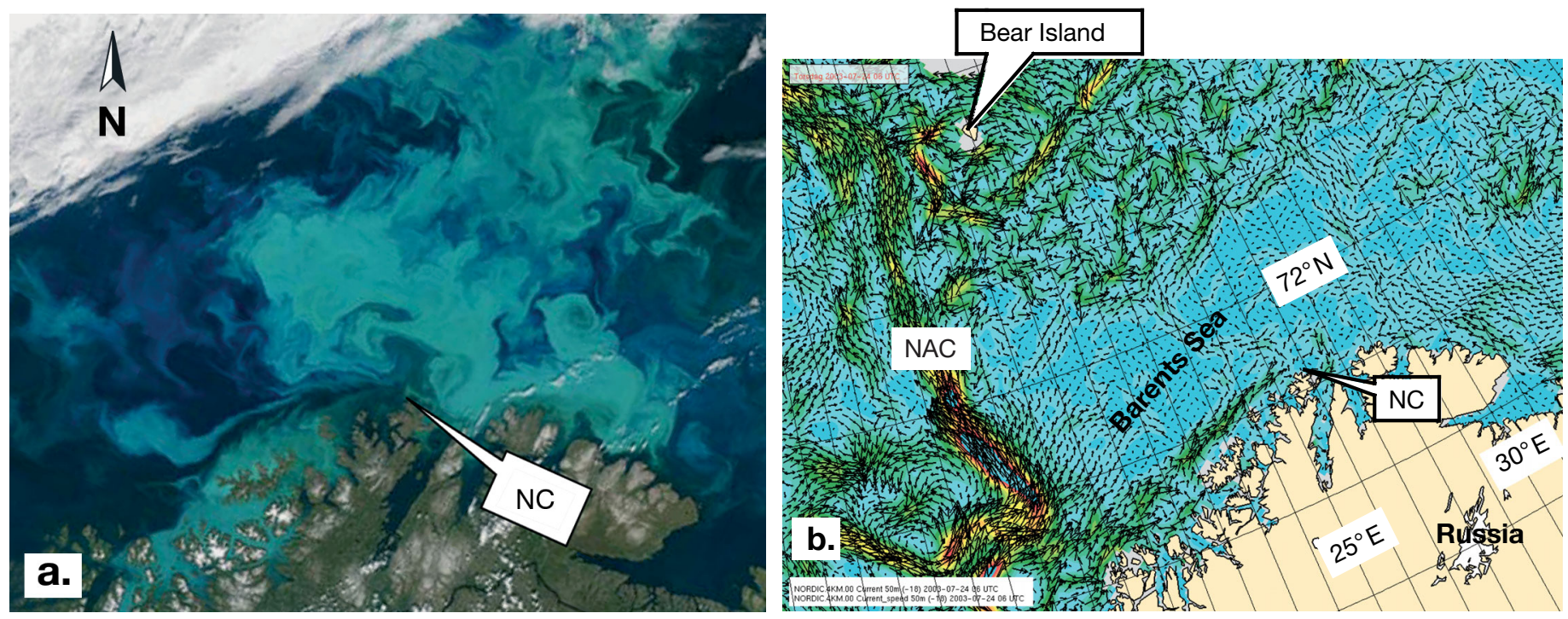

Fig. 5. (a) Barents Sea as seen by the Moderate Resolution Imaging Spectroradiometer (MODIS), captured by the Aqua satellite on July 19, 2003 (spatial resolution: $250 \mathrm{~m}$ ). The bright turquoise areas are blooms of phytoplankton, probably the coccolithophore Emiliania huxleyi. NC: North Cape. (b) An ocean model forecast showing the sea surface current at practically the same time (July 24, 2003), using the forecast system of the Norwegian Meteorological Institute. Arrow length is proportional to current strength, which is also indicated by the colors from light blue (weak) to yellow and red (strong). The latitude-longitude grid has a resolution of $1^{\circ}$. NAC: the Norwegian Atlantic current 
metric $\mathrm{t} \mathrm{yr}^{-1}$. However, its economic importance is partly indirect in that: (1) it comprises the most important prey item for the cod (Kjesbu et al. 1998, Marshall et al. 1999); (2) both capelin and herring are important sources of fishmeal and fish oil, and thereby contribute (as fish food) to the huge Norwegian aquaculture sector (Norwegian farmed Atlantic salmon, $570000 \mathrm{t} \mathrm{yr}^{-1}$, accounts for almost half of the world's Atlantic salmon production).

In the context of biodiversity, these 3 fish stocks are vitally important as prey for large populations of seabirds (20 million in the summer) and large populations of seals and whales. They also play an important role in energy and nutrient flow. For instance, capelin is the only species able to effectively exploit the rich plankton bloom along the ice edge (Gjøsæter \& Loeng 1987 , Hassel et al. 1991, Gjøsæter et al. 2002). It effectively transports a substantial amount of energy from the remote central and northern Barents Sea to coastal areas, where it becomes easily available to piscivorous fishes, seabirds, mammals and fisheries restricted to the southern parts of the Barents Sea. In contrast, much of the biomass accumulated by the herring moves out of the Barents Sea when the 3-yr old herring returns to the Norwegian Sea.

This review does not deal with other fish stocks in the LBS, such as the coastal cod stocks, haddock Melanogrammus aeglefinus, saithe Pollachius virens, 2 species of redfish Sebastes spp., and Greenland halibut Reinhardtius hippoglossoides, although they are (or have been) important both economically and ecologically.

\section{EFFECTS OF OIL SPILLS ON FISHES}

When assesing the effects of oil exploration, the EIAs consider issues such as the amount of stranded oil, the length of the affected coastline, and the regional probability of an impact in the case of an accidental oil spill. In impact studies for the LBA area, various approaches have been applied to examine transport of oil after an accidental oil spill and its impact on fishes. The ocean currents that advect oil were initially derived from monthly climatologies and empirical relations between currents and winds for the 35 yr period 1955 to 1990 (Rudberg 2003a).

Results from 3-dimensional hydrodynamic ocean circulation models were used in the EIA on fish stocks (Johansen et al. 2003). Ocean circulation simulations were performed with 2 different models. The duration of both simulations was limited to a single model year because of the intensive use of computer resources required. A grid mesh with a horizontal resolution of $4 \mathrm{~km}$ was applied in the simulations, and tides were included in both cases. At this resolution, the results reveal the presence of ocean circulation features such as meanders and ocean eddies in addition to larger scale circulation structures. The simulation of egg and larvae advection was based on model results for currents for the relevant year. Oil was assumed to be spilled from 1 of 6 possible locations in the area (Fig. 3). From the simulations, Johansen et al. (2003) calculated how large a fraction of the population would be exposed to $90 \mathrm{ppb}$ of the water-soluble fraction of oil (or $8000 \mathrm{ppb} \times$ hours; see same section below).

An oil spill from the surface from either a platform or a ship will form a plume on the surface downstream from the source. Although oil (density 0.79 to $1.00 \times$ $10^{3} \mathrm{~kg} \mathrm{~m}^{-3}$ ) is lighter than seawater (density $1.03 \times$ $10^{3} \mathrm{~kg} \mathrm{~m}^{-3}$ ) some of it will enter the water column below the slick by dispersion through wave action and by vertical mixing and chemical dissolution. The extent of dispersion depends on the composition of the oil as well as on the weather (wave energy). Dissolution is a less important pathway, since the most soluble substances are light aromatics (e.g. benzene, toluene), which are the first to be lost through evaporation (ITOPF 2002). Oil persistence depends on many factors, especially density (ITOPF 2002). The oil of the LBS area is of medium density, 0.86 to $0.91 \times 10^{3} \mathrm{~kg} \mathrm{~m}^{-3}$ or American Petroleum Institute (API) gravity 24 to 33 (Rudberg 2003b), i.e. with a persistence in the order of months (National Research Council 1985). The oil in some areas has a high wax content (up to $13 \%$ ) and is thus fairly viscous (1.968 Pa $\times \mathrm{s}$ ) (Rudberg 2003b). At low temperatures, natural breakdown of such oil is slow and cannot be effectively combated with dispersants (ITOPF 2002). The oil on board Russian export tankers varies in quality, but the Russian Export Blend Crude Oil (REBCO, or 'Urals') typically has a density of around $0.87 \times 10^{3} \mathrm{~kg} \mathrm{~m}^{-3}$.

We focus on the long-term population consequences of oil impacting early stages of the fishes, i.e. eggs and larvae (Fig. 2) for 2 reasons: (1) In laboratory studies, adult fishes were able to detect petroleum at very low concentrations (Hellstrøm \& Døving 1983, Dauble et al. 1985, Beitinger 1990, Farr et al. 1995); (2) large numbers of dead fishes have seldom been reported after oil spills. Thus, juvenile and adult fish appear to be capable of avoiding water with high hydrocarbon concentrations. One notable exception was the oil spill following the 'Amoco Cadiz' ship accident, which killed large numbers of fishes, including a locally high proportion of 1 yr-old fishes of the commercially important plaice and sole. This was probably due to massive amounts of emulsified oil in the shallow waters where the spill occurred (IPIECA 1997). Oil at very low concentrations (ppb levels) can also 'taint' adult fishes (i.e. impart unpleasant odours and flavour to their flesh). 
Fishes can become tainted directly from the water or from sediments (via absorption through the gills and skin), or through contaminated prey species (IPIECA 1997). The slightest suspicion of tainting or that fishes may constitute a human health hazard can render them unmarketable for extended periods (Birtwell \& McAllister 2002). For this reason, fishing is sometimes banned in the area of an oil spill. Also, oil-polluted sediments may negatively affect burrowing fishes such as flatfishes or sandlance in several ways (see Birtwell \& McAllister 2002 and references therein). However, the focal species of the present review are not closely linked to the seabed.

In contrast to juveniles and adults, fish eggs and larvae are planktonic and thus unable to escape from polluted water; they are exposed to any toxic compounds the water may contain. The toxicity of oil for fish eggs and larvae has been reviewed, for example, by Clark (2001). Toxicological mechanisms are complex, as crude oil is a mixture of different hydrocarbons and other organic and inorganic substances, and its composition varies greatly between oil types. In addition, the perseverance and toxicity of oil are affected by several other factors such as weathering, dispersion and emulsification, which again depend on external factors such as weather conditions. Toxicological laboratory studies on animals typically use oil itself (fresh or weathered), the light aromatics benzene, toluene, ethylbenzene, and xylene (the BTEX components, which make up 80 to $90 \%$ of the water-soluble fraction), or the polycyclic aromatic hydrocarbons (PAHs). The toxicity of fresh oil is correlated to its PAH content, which therefore has been thought to be the primary toxin of oil. However, toxicity and PAH are not correlated in weathered oils (Barron et al. 1999). In addition, toxicity test procedures typically use $25^{\circ} \mathrm{C}$ water and warm-water organisms, which may be more robust than cold-water organisms (Perkins et al. 2005). Relatively few studies have been performed on eggs and larvae of the organisms reviewed in the present paper. Booman et al. (1995) tested the susceptibility of NEA cod larvae to BTEX, and found them to be relatively susceptible compared to those laboratory organisms more commonly used in toxicity tests. For instance, yolk-sac larvae of NEA cod showed reduced oxygen uptake when exposed for $24 \mathrm{~h}$ to $20-80 \mathrm{ppb}$ of the water-soluble fraction of oil. However, Booman et al. (1995) found no effects on growth or first feeding success. Toxicological studies have also traditionally been conducted in the absence of UV light, but the toxicity of $\mathrm{PAH}$ and weathered oil has been found to increase with a factor of 2 to $>1000$ in the presence of sunlight (Barron et al. 2003). The use of chemical dispersants to avoid stranded oil on the beaches will in general increase the toxic effects of oil on fish larvae, at least temporarily
(Couillard et al. 2005). In the EIA for the LBS, Johansen et al. (2003) found the lowest $\mathrm{LD}_{50}$ (concentration leading to $50 \%$ mortality) to be 900 ppb among 93 studies of planktonic organisms (the studies used different types of oil products and either invertebrates, fishes or algae). Using a security factor of 10, they set the predicted no-effect concentration (PNEC) at $90 \mathrm{ppb}$ $\left(\mu \mathrm{g} \mathrm{l}^{-1}\right)$ hydrocarbons. Since most studies used a $96 \mathrm{~h}$ exposure, this is equivalent to approximately 8000 $(90 \times 96) \mathrm{ppb} \times \mathrm{h}$.

A critical issue that has arisen in recent years, in particular following the 'Exxon Valdez' accident, is the effect of sublethal damage to eggs and larvae. Although acute lethality tests are useful for generating guidelines to protect against physiological death (i.e. mortality), they ignore 'ecological death', i.e. pollution damage that renders fishes unable to function in an ecological context, even if they are not visibly harmed (Scott \& Sloman 2004). PAHs cause a range of abnormalities such as morphological deformities and cytogenetic abnormalities (Hose et al. 1996) and embryonic cardiac dysfunction (Incardona et al. 2004). More subtle, but possibly serious effects include lasting disruption of complex behaviour, such as predator avoidance, reproductive and social behaviour (Scott \& Sloman 2004). For fish eggs that develop in intertidal sediments, such as Pacific herring and pink salmon, such effects can result from PAH concentrations as low as $0.4 \mathrm{ppb}$ (Carls et al. 1999). It has also been shown that weathered crude oil can cause immunosuppression and expression of a viral disease, viral hemorrhagic septicemia virus (VHSV). The 1989 Pacific herring year-class, which was exposed to 'Exxon Valdez' oil at the egg stage, displayed a high incidence of VHSV as well as an extremely low survival until the age of spawning. This caused a dramatic collapse of the stock in 1993. Carls et al. (2002) argued that the 'Exxon Valdez' oil spill might, at least partly, have caused this collapse, although this could not be conclusively demonstrated.

\section{WHAT AFFECTS THE IMPACT OF AN OIL SPILL ON A FISH POPULATION?}

The effect on a fish population of an oil spill in an area with fish larvae depends to a great extent on oceanographic and ecological conditions. The extent of the spill, the weather conditions at the moment of impact, the time of year and several ecological aspects all influence the extent of the impact on the year-class affected. Below, we discuss some of these aspects. While the current EIA is in general scientifically sound, there are some topics which it deals with fairly superficially. 


\section{Physical state of the ocean, especially mesoscale circulation}

The oceanic conditions at the time of the spill and immediately afterwards affect the advection of both oil and spawning products. The amount of oil that is dissolved and dispersed from the spill site into the water column depends on the weather, ocean conditions, and location and depth of the spill (spills at the sea bottom give rise to different hydrocarbon concentrations than surface spills). Almost all the existing oil pollution impact studies for Norwegian waters have been based on empirical relations between historical winds and ocean currents. The wind strength in the LBS area can be characterised by the North Atlantic Oscillation (NAO) index (Ottersen et al. 2001, Stenseth et al. 2002, Hurrell et al. 2003, Stenseth et al. 2003). This index is a measure of the strength of the North Atlantic westerlies, which have a significant impact on the strength and position of the NAC (Orvik et al. 2001). However, the weather in this region is not solely determined by the NAO, which is why an approach using historical winds has been considered preferable to simply deducing the impact from the NAO. With this approach, ocean circulation features will be on the same scale as the atmospheric scale, with possible modifications for coastal areas. However, because of the different properties of air and water, oceanic scales are smaller than atmospheric scales by a factor of $1 / 10$ to $1 / 100$ (Charney \& Flierl 1981).

Smaller scale oceanic features comprise eddies, filaments and meanders ('mesoscale features') (Fig. 5). These mesoscale features influence how oil spills affect biological activity in the ocean. Generally, the water mass of an eddy differs from its surroundings. An eddy traps particles and dissolved material (e.g. fish eggs and hydrocarbons, if present) until the eddy dissipates or is dispersed. In order to include mesoscale effects, the results of hydrodynamic ocean-circulation models have
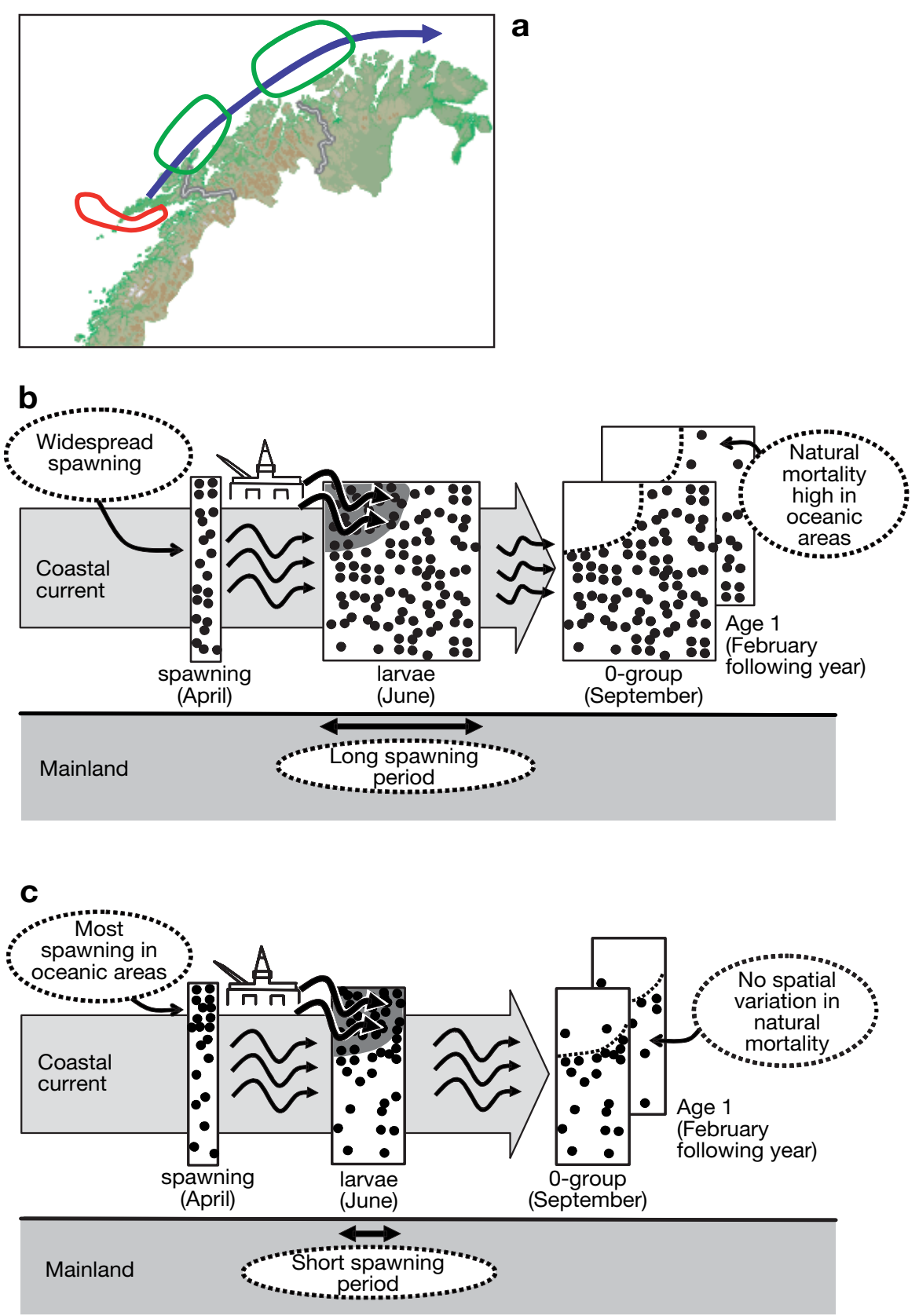

Fig. 6. Biological and oceanographic factors may determine how an oil spill affects mortality in cod larvae, and thus the North-east Arctic (NEA) cod stock. (a) Red: spawning areas; green: position of the eggs and larvae in April and May; blue arrow: movement of fish eggs and larvae with currents (NCC and NAC). (b,c) Location of a year-class of NEA cod at 4 stages: eggs at the main spawning grounds of Lofoten, larvae drifting along the coast in the Norwegian Coastal Current (NCC), 0-group fish in the Barents Sea, and $1 \mathrm{yr}$ olds at roughly the same location as the 0-group. An oil spill in the oceanic part of the NCC kills part of the larval population (shaded area), with small impact in (b) and large impact in (c). (b) Cod spawning occurs throughout coastal and oceanic sites over an extended period, resulting in a long train of cod larvae; the oil spill only kills larvae that would have had a small chance of surviving the first winter. (c) Cod spawn mostly in the oceanic areas and for a short period, resulting in a more concentrated distribution of larvae, and the larvae killed by oil would have had an average (or higher) chance of future survival. Oceanography determines the degree of mixing (i.e. spatial distribution from eggs to larvae to the 0-group stage) 

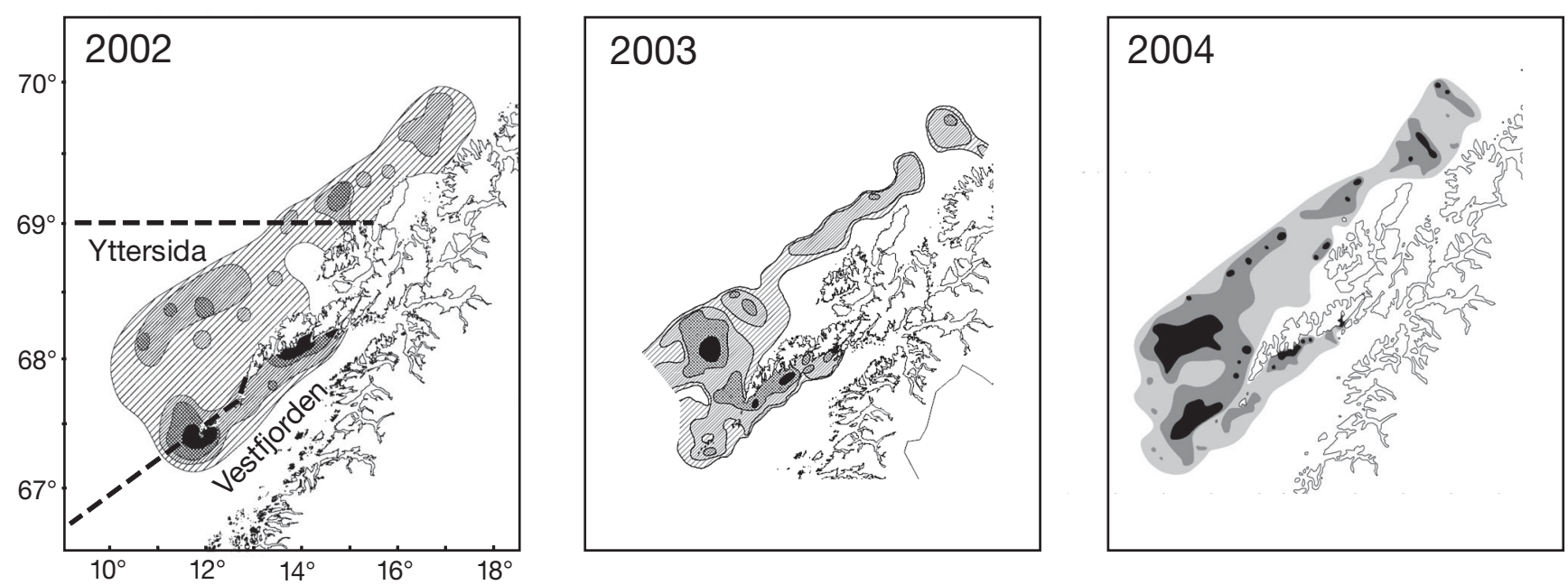

Fig. 7. Gadus morhua. Spatial distribution of spawning North-east Arctic (NEA) cod in 2002 to 2004 in the coastal area Vestfjorden and the more oceanic area of Yttersida (indicated on the left map: Salthaug 2002, Mehl \& Nedreaas 2003, Mehl 2004). Shading indicates the strength of acoustic registrations of cod (darker shading = high density of cod spawners). See Table 1 for additional data

recently been used in impact studies. As mentioned in an earlier subsection, results from 2 such simulations were used in the EIA for the LBS area (Johansen et al. 2003). A horizontal resolution of $4 \mathrm{~km}$ allows for mesoscale features to be represented in such simulations (exemplified in Fig. 5). Nevertheless, the use of such results for calculation of mesoscale statistics is questionable for 2 reasons: (1) the use of a single model year in each simulation means that this does not reflect year-to-year variability in the larger-scale ocean circulation associated with (e.g.) the NAO index, and its impact on mesoscale structures. Largescale ocean circulation provides the energy for mesoscale motion since energy arising from largescale stratification and momentum is converted into mesoscale energy (e.g. Fossum 2006, Fossum \& Røed 2006). (2) A single realization for each period means that the small-scale variability associated with the stochastic nature of flow instability is not included. In order to describe the statistics associated with mesoscale variability, a proper ensemble of simulations (i.e. a set of realizations of the system) must be computed,

Table 1. Gadus morhua and Mallotus villosus. Stock data for the spawning periods shown in Fig. 7

\begin{tabular}{|ccccc|}
\hline $\begin{array}{c}\text { Cod stock } \\
\text { in Vestfjorden } \\
(\%)\end{array}$ & $\begin{array}{c}\text { Cod standing } \\
\text { stock biomass } \\
\left(10^{3} \text { metric }\right)\end{array}$ & $\begin{array}{c}\text { Cod first-time } \\
\text { spawners } \\
(\%)\end{array}$ & $\begin{array}{c}\text { Capelin } \\
\text { biomass } \\
\left(10^{3} \text { metric } t\right)\end{array}$ \\
\hline 2002 & 36 & 158 & 57 & 3500 \\
2003 & 21 & 263 & 83 & 2100 \\
2004 & 4 & 286 & 38 & 700 \\
\hline
\end{tabular}

similar to the manner in which medium-range weather forecasts are routinely produced.

\section{Distribution of spawning sites}

The only way in which fishes can 'decide' where to be at the egg and larval stages is by the parents' choice of spawning time and site (Fig. 7), and by the density of the eggs (which determine their average depth). For each of the 3 species, the proportion of individuals spawning at each spawning location varies substantially between years. Herring spawning sites can change dramatically both from one year to the next and on multidecadal time scales. The spawning pattern of cod is more stable, but there is still considerable variation in the distribution of spawning cod among the main areas of Lofoten (Vestfjorden and Yttersida; Fig. 7, Table 1). Spawning capelin have an easterly distribution $\left(28^{\circ}\right.$ to $\left.33^{\circ} \mathrm{E}\right)$ in some years and a westerly distribution $\left(18^{\circ}\right.$ to $\left.31^{\circ} \mathrm{E}\right)$ in others (Gjøsæeter et al. 1998). Changes in temperature, stock size or mean age of the spawning stock, and changes in egg predation from herring are possible explanations for the observed patterns. However, there is no simple relationship between (e.g.) stock size and climatic conditions.

Year-to-year variability in the spawning area may be correlated with the severity of the impact from an oil spill, since certain ocean circulation regimes (correlated with weather patterns such as NAO) may be associated with both anomalous hydrocarbon con- 
tents from an oil spill, and with a shift in the preferential spawning site. A change in spawning area or time of spawning will thus affect the drift pattern of eggs and larvae which, in turn, will affect the probability of contact with oil from an oil spill.

\section{Length of the spawning season as an ecological and evolutionary consequence of harvesting}

To fully understand external influences such as fishing pressure and perturbations such as oil spills, it is important to study their impact on the lifehistory traits of the relevant population. Decrease of genetic variation may lead to a population that is more susceptible to environmental disturbances such as oil spills by reducing its ability to adapt and respond to stress. A growing body of evidence suggests that high fishing pressure and size-selective harvesting may result in fisheries-induced evolution of some life-history traits (Heino \& Godø 2002), including age and size at maturation (Heino et al. 2002a,b, Barot et al. 2004, Ernande et al. 2004, Olsen et al. 2004). In the case of NEA cod, the decrease in age and size at maturation observed since 1950 has been suggested to be not only a plastic but also a genetic response to a high fishing pressure, as well as changes in the fisheries' size selectivity (Heino et al. 2002b, Eikeset et al. 2005). Other life-history traits may also be affected by fisheries-induced changes; e.g. individual growth rate (Conover \& Munch 2002) and reproductive investment (Reznick et al. 1996, Reznick \& Ghalambor 2005, Rijnsdorp et al. 2005). Therefore, it is important to take fishery-induced evolution into account when assessing the sensitivity of fish populations to oil spills. In the case of cod, it has also been shown that compared to first-time spawners, older individuals that have spawned before ('repeat spawners') arrive earlier on the spawning grounds, spawn over a longer time span, producing several times more eggs during the spawning season and over a wider range of vertical distribution (Kjesbu et al. 1992, 1996, Marshall et al. 1998). As a result, eggs and larvae of repeat spawners spread out much more horizontally, vertically and temporally, the 'plume' of eggs and larvae downstream from the spawning site is longer, and therefore the population will be less susceptible to oil spills (Fig. 6). Since the 1950s, the proportion of older, larger cod has decreased dramatically. While $90 \%$ of the spawning stock biomass originated from fish of age $10 \mathrm{yr}$ and older in 1947, this value was $2.5 \%$ in 2002 (Ottersen et al. 2006). Therefore, cod eggs and larvae have become increasingly concentrated in space and time, and thus the consequences of an oil accident may be more severe. Physical conditions also influence the distribution and advection of eggs and larvae (e.g. the less wind, the more larvae will remain high in the water column, where concentrations of hydrocarbons are highest).

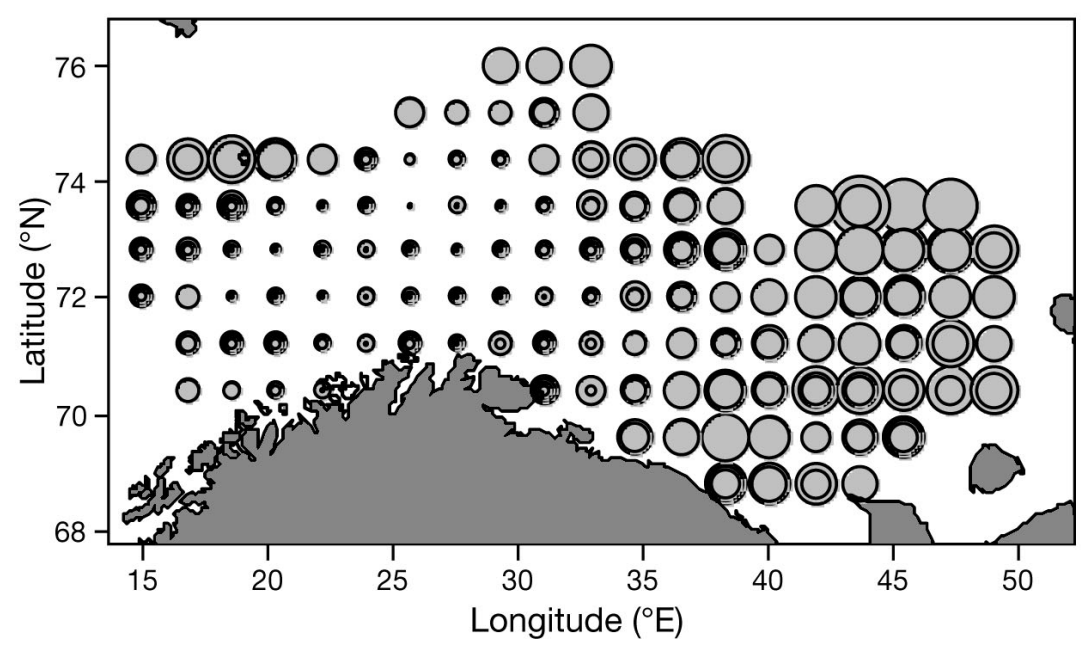

Fig. 8. Gadus morhua. Spatial patterns of North-east Arctic cod survival from age $5 \mathrm{mo}$ (September) to age 11 mo (February), during the period from 1980 to 2004, as estimated by an additive GAM model including geographic coordinates (latitude and longitude), bottom depth, fish length and winter temperature as covariates. Circles are proportional to the relative survival (i.e. larger circles show better survival). Circles of different sizes within the same grid location reflect the interannual variability of the survival metric (from Ciannelli et al. 2007)
Natural mortality and species interactions subsequent to oil spill mortality

In the absence of human interference, there is enormous natural mortality of many fish species from the larval stage to the time when they recruit to the fisheries. For instance, for NEA cod, survival is in the order of $10^{-6}$ from eggs to age 3 yr (i.e. 1 out of 1000000 eggs survives). Still, this mortality appears to vary a good deal between years (in the order of $\sim 10$ for NEA cod) and between areas. The survival of NEA cod from age 5 mo to age 11 mo appears to vary substantially spatially as well, being higher in the eastern Barents Sea (Ciannelli et al. 2007; see also present Fig. 8). One possible reason is that small cod may be 'protected' from cannibalism in colder waters (Ciannelli et al. 2007). Since an oil spill kills larvae in a limited area, this will influence the degree to which the population is affected 


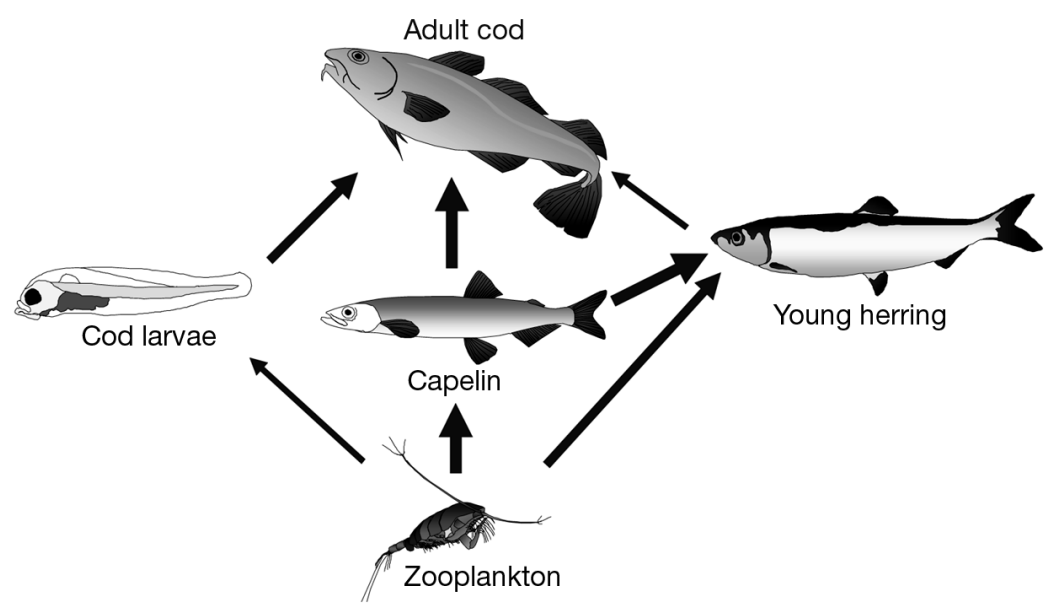

Fig. 9. Gadus morhua, Mallotus villosus and Clupea harengus. Trophic relationships between the main components of the food web, including cod cannibalism

by the oil spill. For instance, assuming that an oil spill kills $20 \%$ of the fish larvae, and that these $20 \%$ were larvae that would have been advected to ecologically unfavourable areas and thus have suffered $100 \%$ mortality, then the real effect of the oil spill would be close to zero when the cohort reaches fishable age (e.g. age 3 yr). On the other hand, if the $20 \%$ larvae killed were those that would have been advected to favourable areas and thus have had the best chance of survival, then the final effect would be more than $20 \%$. Therefore, an understanding of the spatial variability in survival and its causes is crucial (Fig. 6). The fact that an oil spill does not affect all eggs or larvae equally can affect the conclusions about the effects of an oil spill. For instance, according to Johansen et al. (2003: their Fig. 7.8), an oil spill from the 'Troms I' petroleum region will tend to affect/kill cod larvae in the eastern part of their distribution area. Assuming that these will also have an easterly position at the 0 -group stage, these larvae are those with the best chance of survival from the 0-group stage to age 1 yr (Ciannelli et al. 2007; Fig. 8).

Even if the primary effect of an oil spill was to reduce a single year-class of a single species, ecological interactions would lead to secondary effects arising from predation, competition and cannibalism (Fig. 9). Such effects could be either intraspecific (e.g. changed growth and life-time among the surviving portion of the year-class as well as other year-classes) or interspecific (i.e. changes in temporal distribution, growth and survival among the prey, predators and competitors of the species affected by oil). Intraspecific secondary effects can reduce or increase the primary effect, (compensation or depensation, respectively). Compensation is expected if the stock is bottom-up controlled (i.e. if prey is the limiting factor). For instance, if $15 \%$ of the cod larvae were killed by oil (primary effect), reduced competition among the survivors might partly compensate for the mortality, reducing the year-class by $<15 \%$ at age 3 yr. On the other hand, in a stock subjected to topdown control (i.e. predation, including cannibalism) the result might be depensation (i.e. the fish might suffer higher predation mortality if the year-class had been weakened by an oil spill). In this example, the year-class could ultimately be reduced by $>15 \%$ at age $3 \mathrm{yr}$ as a result of the oil spill. Whether compensation or depensation occurs may well depend on the ecological and/or climatic state of the ecosystem. In the case of cod, a mechanism for such shifts could be cannibalism, which is more prevalent when the capelin stock is small. Thus, the early survival of cod may be bottomup controlled when capelin is abundant and top-down controlled when capelin is scarce.

Interspecific secondary effects are highly likely in the LBS system since the 3 species are strongly interlinked (e.g. Dingsør et al. 2007, Hjermann et al. 2007): (1) Capelin is a key food source for cod, and thus high capelin biomass has a significant positive effect on cod, reducing cannibalism, and increasing reproductive output of the latter (Marshall et al. 1999). Likewise, cod predation has a significantly negative effect on capelin survival (Hjermann et al. 2004c). (2) Capelin recruitment is heavily affected by predation by juvenile herring on capelin larvae; the capelin population can collapse (decrease by $>95 \%$ ) following years with abundant juvenile herring (Gjøsæeter \& Bogstad 1998). Because of their intimate interdependence, all 3 stocks are likely to be affected should only one of them be directly exposed to pollution. The extent and duration of such cascading effects depends on the structure of the ecosystem and the strength of interactions, which to some degree is known for at least the Barents Sea ecosystem (Tjelmeland \& Bogstad 1998, Bogstad et al. 2000). Also, if an oil spill directly disrupts the temporal distribution of only one trophic level, other trophic levels may become temporally mismatched, thus weakening trophic links - the essence of the match-mismatch hypothesis (Hjort 1914, Cushing 1990, Durant et al. 2007).

\section{Chronic sublethal effects of persistent oil residues}

The immediate effects of oil spills are reflected in acute mortality of sea birds and oceanic mammals 
through oil slicks. However, the 'Exxon Valdez' oil spill has shown that the mortality immediately following an oil spill can be less damaging than long-term (e.g. a decade) chronic exposure to persistent oil residues in the environment (Peterson et al. 2003). Many of the populations that suffered heavy shortterm mortality in the 1989 'Exxon Valdez' spill have recovered, but not all-some populations are still recovering slowly and some not at all. 15 years after the accident, significant amounts of 'Exxon Valdez' oil remain in intertidal and subtidal sediments and below mussel beds. Thus, species such as sea otters and harlequin ducks that prey on benthic organisms, still exhibit increased levels of the detoxification enzyme CYP1A, and suffer higher mortality in the area impacted by the spill (Peterson et al. 2003). The elevated level of toxicity also impacts those fishes whose eggs develop in intertidal habitats. One example is that among pink salmon exposed to $<20$ ppb PAHs as embryos, only half the number of fishes survived the next $1.5 \mathrm{yr}$ at sea compared to control salmon (Heintz et al. 2000). Among the 3 fish stocks that are the focus of our study, capelin and herring may also be at such risk (cod spawn their eggs pelagically). NSS herring spawn on the Norwegian coast south of the LBS, whereas the capelin's spawning sites are close to the coast within the LBS (Fig. 1), on sandy/gravel bottom plains in relatively shallow water (10 to $60 \mathrm{~m}$ depth). Their eggs are attached to bottom gravel where the embryos develop for a period of 3 to $8 \mathrm{wk}$. If this gravel is contaminated, then, as adults, the capelin could suffer from sublethal effects (such as behavioural changes or reduced fecundity) arising from their exposure as embryos (Heintz et al. 2000). Substantial sedimentation of oil occurred after the 'Prestige' and 'Exxon Valdez' oil spills. In the case of the 'Prestige', the oil spilled comprised very heavy fuel oil of much higher density than that found offshore from Norway. However, even quite light oil can sink when it adsorbs onto sediment particles, and the chances of this occurring are increased in coastal waters, which (especially in spring), are of low density and contain a high amount of suspended particles. In the case of the 'Exxon Valdez', 8 to $15 \%$ of the oil sedimented in shallow coastal areas (Wolfe et al. 1994). In the 'Braer' spill, large amounts of very light North Sea oil (Gullfaks) were deposited on the sea bed due to strong winds and turbulent conditions: High wave energy dispersed the oil throughout the water column, where it adsorbed to the suspended sediment particles and sank. Fishes and shellfishes were not tainted and the concentration of PAHs returned to reference levels after 2.5 yr. However, analyses of mussels and sediment cannot exclude more long-lasting contamination (Webster et al. 1997, 2000, 2001).

\section{QUANTIFICATION OF OIL SPILL IMPACT ON THE FISH STOCKS}

As shown by Fig. 2, the impact of an oil spill on fish stocks depends on many factors, each of which involves considerable stochasticity. In order to quantify the total effect, these need to be integrated in the quantification approach. A powerful approach for making such a complex evaluation is a Monte Carlo simulation ${ }^{1}$ on all the factors simultaneously. Such simulation should be performed sequentially, as indicated by the arrows in Fig. 2, and will provide a simulation of the structure (size and age distribution) of the population. Repeated simulations can be used to estimate the impact of oil spills and associated uncertainties.

The impact of an oil spill may be quantified either at an aggregated level (i.e. the average effect of an oil spill of a certain duration) or made more specific with respect to the location and time of an oil spill. Aggregated quantities are useful as measures of the total impact of oil spills. They can, however, be misleading. For instance, a predicted mean decrease in a fish population of $5 \%$ could indicate that the actual decrease would be $\sim 5$ for oil spills at most locations and most times, or, alternatively, that there would be no population decrease in most oil spills but very high decreases in a few cases. The different causes to the mean decrease of $5 \%$ can be interpreted as different levels of risk. Impact assessments related to specific oil spill scenarios can therefore give more detailed information. Johansen et al. (2003) considered impact assessments for specific spill locations at specific times of the year.

One could consider specifying other factors or scenarios as well, such as years with high and low NAO indexes. In cases where it is not possible to assign a probability for each scenario, impact should be reported for each scenario individually rather than aggregated over all scenarios. Monte Carlo procedures are powerful tools in this respect, in that small changes in the simulation procedures change the measures from aggregated to specific levels.

Uncertainties in the predicted effects appear because of stochastic processes such as flow instabilities. These processes are typically described by models whose results depend on other uncertainties, such as the initial state, atmospheric forcing, and flow across open boundaries. Although some relevant information

\footnotetext{
${ }^{1}$ Monte Carlo methods are stochastic techniques (i.e. based on the use of probability statistics to examine problems for which one or several aspects are influenced by uncertainties or randomness). The output of such techniques can give average impacts for the possible scenarios, and in addition uncertainties about such quantities.
} 
may be gained by direct observation, some (in many cases considerable) uncertainties will always remain. While such uncertainties can be integrated in the Monte Carlo procedure, this source of uncertainty is typically ignored.

\section{KNOWLEDGE GAPS AND RESEARCH NEEDS}

The biological effects of oil spills are generally extremely hard to predict. Their impact is affected by so many parameters that the effects of no 2 oil spills are the same. The amount of oil spilled is hardly correlated with the ecological impact of the spill. Measured in the amount of oil spilled, the 'Exxon Valdez' oil spill ranks only as no. 40 among oil spills that occurred between 1967 and 1994, but cost Exxon 3.5 billion dollars in direct expenses (ExxonMobil 2004). In comparison, 15 times as much oil was spilled in the IXTOC I blowout in the Mexican Gulf in 1979, and 6500 times as much in the Persian Gulf in 1991 (Paine et al. 1996). An oil slick that was barely visible killed 10000 seabirds in a fiord close to Vardø, Northern Norway in 1979 (Bambulyak \& Frantzen 2005). Thus, ecological impact is obviously determined by other factors in addition to spill size, such as location (closeness to shoreline), time of year, atmospheric as well as oceanic conditions at the time of the spill, and type of oil. However, as we have attempted to show herein, the effects of an oil spill also depend in more subtle ways on its interactions with prevailing oceanographic and ecological conditions. Thus, assessing the potential effects of oil spills demands careful consideration of both the physical and the biological processes involved.

With regard to physical processes, drift trajectories, and hence the region of influence of a potential accidental oil spill, are traditionally computed using an empirical relationship between surface winds and the ocean current with which the oil spill is advected. Thus, based on wind data from an atmospheric circulation analysis, drift trajectories are completely deterministic. In one sense, the ocean is subservient to the atmosphere: In a hypothetical case of 2 years with identical atmospheric forcing, the ocean circulation, and drift trajectories, becomes identical. However, as demonstrated by the results of recent ocean circulation studies using an ensemble of realizations, the relationship between ocean circulation and atmospheric forcing is not deterministic (e.g. Metzger \& Hurlburt 2001, Melsom et al. 2003). In a study with a mesh configuration (i.e. grid size and map projection) similar to the simulations of Johansen et al. (2003), Melsom (2005) found that in frontal regions, about $1 / 3$ of the variability can be attributed to the non-deterministic variability associated with flow instabilities resulting in meso- scale features such as eddies, filaments and meanders (e.g. Fossum 2006, Fossum \& Røed 2006). This is in fact an underestimate, since the variance in the probability distributions for (e.g.) salinity and temperature was underestimated in Melsom's (2005) study.

In order to fill the gaps on physical aspects in our knowledge of how oceanic transport of oil will affect its impact on marine life, we must address the 2 issues not yet appropriately analyzed in the existing impact studies of the LBS area: (1) How does large-scale variability affect mesoscale circulation and thereby the variability of transport pathways, and (2) what is the probability distribution of transport pathways associated with non-deterministic variability? In order to resolve question (1), a hydrodynamic model must be applied to a time period that spans various atmospheric forcing regimes in a manner that reproduces mesoscale features. Question (2) is resolved by an ensemble simulation, whereby the results have a probability distribution that is similar to the observed distribution.

Both approaches are computationally demanding. The fact that the hydrodynamic model of Johansen et al. (2003) was limited to two 1 yr simulations was probably due to the limits of the computer resources available at that time. This situation is changing. Moreover, an ocean circulation ensemble that exhibits a proper probability distribution in the context of mesoscale variability is yet to be defined, and constitutes a scientific challenge, since the mesoscale circulation is not resolved by synoptic observations in space and time. We suggest that inclusion of continuously perturbed atmospheric forcing fields will yield more realistic probability distributions than the approach using initial state perturbations of decadal simulations that were performed by Melsom (2005).

With regard to ecological aspects, we have pointed to some 'unknowns' for these 3 species. This may seem paradoxical, since cod and herring have been in the focus of Norwegian fishery science for more than 100 years. However, even for NEA cod, one of the beststudied fish stocks in the world, there are gaps in our knowledge that significantly hamper our ability to predict the effects of an oil spill. This is illustrated by the 'Exxon Valdez' spill, for which it has proved difficult to assess the oil spill damage and the recovery time even in the case of populations that had been very well-studied prior to the accident, such as the killer whale Orcinus orca and pink salmon Oncorhynchus gorbuscha.

We believe, however, that existing predictions for possible oil spill impacts can be improved by using available data. Typically, the expected impact of an oil spill is given as a function of approximate location (e.g. distance from the coast) and time of year (month). Oceanographic models should be able to provide more 
detailed guidance on the risks associated with spills at different locations. Also, as detailed above, the impact will depend on the ecosystem's ecological state (abundance of key species, such as capelin in the case of LBS) as well as its climatic state (e.g. high or low NAO years). These variables can affect both the location/ distribution of eggs/larvae, the drift patterns of both eggs/larvae and oil, as well as the consequences to fish populations (including effects of ecosystem interactions) of oil-caused mortality at the larval stage. With regard to possible cascade effects of oil spills causing larval mortality, oil spills comprise but one kind of pulse perturbation (e.g. Chan et al. 2003), and thus other kinds of perturbations (i.e. climatic and ecological conditions causing mortality in specific life stages) can provide insight into such cascade effects. Ecological/genetic models can predict the combined effects of fisheries and oil on fish dynamics, i.e. how fisheries affect susceptibility of fish stocks to oil spills and vice versa.

Even in a pristine state, the Barents Sea-Norwegian Sea ecosystem may not be characterised by balance and stability. For instance, recruitment (i.e. larval mortality) of the herring, a key species in this system, is extremely variable from year to year, in part because of variations in the oceanic climate (Fiksen \& Slotte 2002). Hence, the ecosystem is inherently stochastic: Even with a perfect knowledge of the system and the lethal and non-lethal effects of an oil spill, we could not predict its effects on the ecosystem for more than a few years ahead. Further, our knowledge on ecosystem processes in this system is imperfect. Since no large degree of certainty can be achieved in any conclusions about long-term effects, at best we can attempt, by modelling, to attain a quantitative indication of the possible outcomes of oil spills in the ecosystem context. Qualitatively, we can assess at which places and times an oil spill may be expected to have the most significant long-term effects, and under which climatic regimes the effect of spills will be most harmful.

Acknowledgements. We thank the following Norwegian Research Council programmes: 'Havet og Kysten' for supporting the LEO (Long-term Effects of Oil accidents) project, and Polar Climate Research for supporting the ECOBE (Effects of the North Atlantic Variability on the Barents Sea Ecosystem) project. We also thank VISTA (www.vista.no) for funding D.Ø.H, and Hydro for financial support. Comments provided by 4 reviewers on an earlier version of the paper are greatly appreciated.

\section{LITERATURE CITED}

Aglen A, Gjøsæeter H, Holst JC, Klungsoyr J, Olsen E (2005) Verdifulle områder for torsk, hyse, sild og lodde i området Lofoten-Barentshavet. Institute of Marine Research, Bergen, Norway
Albretsen J, Røed LP (2006) Sensitivity of Skagerrak dynamics to freshwater discharges: insight from a numerical model. In: Dahlin H, Ryder P (eds) European operational oceanography: present and future. Proc 4th EuroGOOS Conf, June 6-9, 2005, Brest, France. Elsevier, Amsterdam

Anonymous (2003) Utredning av konsekvenser av helårig petroleumsvirksomhet i området Lofoten-Barentshavet. Ministry of Petroleum and Energy, Oslo

Anonymous (2006) New monitoring of the marine environment in the north. Press release from the Ministry of Environment, Norway. Oslo, March 31, 2006

Bambulyak A, Frantzen B (2005) Oil transport from the Russian part of the Barents Region, Svanhovd Environmental Centre, Svanhovd, Norway

Barot S, Heino M, O'Brien L, Dieckmann U (2004) Long-term trend in the maturation reaction norm of two cod stocks. Ecol Appl 14:1257-1271

Barron MG, Podrabsky T, Ogle S, Ricker RW (1999) Are aromatic hydrocarbons the primary determinant of petroleum toxicity to aquatic organisms? Aquat Toxicol 46:253-268

Barron MG, Carls MG, Short JW, Rice SD (2003) Photoenhanced toxicity of aqueous phase and chemically dispersed weathered Alaska North Slope crude oil to Pacific herring eggs and larvae. Environ Toxicol Chem 22: 650-660

Beitinger TL (1990) Behavioral reactions for the assessment of stress in fishes. J Gt Lakes Res 16:495-528

Birtwell IK, McAllister CD (2002) Hydrocarbons and their effects on aquatic organisms in relation to offshore oil and gas exploration and oil well blowout scenarios in British Columbia, 1985. Can Tech Rep Fish Aquat Sci 2391 Fisheries and Oceans Canada, West Vancouver

Blom-Jensen B, Dervo HJ (2003) Sannsynlighet for hendelser med store oljeutslipp (ULB 7e). Scandpower, Kjeller

Bogstad B, Haug T, Mehl S (2000) Who eats whom in the Barents Sea? In: Víkingsson GA (ed) Minke whales, harp and hooded seals: major predators in the North Atlantic ecosystem. North Atlantic Marine Mammal Commision, Tromsø

Booman C, Midtøy F, Smith AT, Westrheim K, Føyn L (1995) Effekter av olje på marine organismer-særlig på fiskelarvens første næringsopptak. Fisken Havet 1995:9, Institute of Marine Research, Bergen

Brakstad OG, Bonaunet K, Nordtug T, Johansen O (2004) Biotransformation and dissolution of petroleum hydrocarbons in natural flowing seawater at low temperature. Biodegradation 15:337-346

Carls MG, Rice SD, Hose JE (1999) Sensitivity of fish embryos to weathered crude oil. Part I. Low-level exposure during incubation causes malformations, genetic damage, and mortality in larval Pacific herring (Clupea pallasi). Environ Toxicol Chem 18:481-493

Carls MG, Marty GD, Hose JE (2002) Synthesis of the toxicological impacts of the Exxon Valdez oil spill on Pacific herring (Clupea pallasi) in Prince William Sound, Alaska, USA. Can J Fish Aquat Sci 59:153-172

Chan KS, Stenseth NC, Lekve K, Gjøsæter J (2003) Modeling pulse disturbance impact on cod population dynamics: the 1988 algal bloom of Skagerrak, Norway. Ecol Monogr 73: 151-171

Charney JG, Flierl GR (1981) Oceanic analogues of largescale atmospheric motions. In: Warren BA, Wunsch C (eds) The evolution of physical oceanography. MIT Press, Cambridge, MA

Ciannelli L, Dingsør GE, Bogstad B, Ottersen G, Chan KS, Gjøsæter H, Stiansen JE, Stenseth NC (2007) Spatial anatomy of species survival: effects of predation and cli- 
mate-driven environmental variability. Ecology 88:635-646

Clark RB (2001) Marine Pollution, Oxford University Press, Oxford

Conover DO, Munch SB (2002) Sustaining fisheries yields over evolutionary time scales. Science 297:94-96

Couillard CM, Lee K, Legare B, King TL (2005) Effect of dispersant on the composition of the water-accommodated fraction of crude oil and its toxicity to larval marine fish. Environ Toxicol Chem 24:1496-1504

Cushing DH (1990) Plankton production and year-class strength in fish populations - an update of the match mismatch hypothesis. Adv Mar Biol 26:249-293

Dalpadado P, Borkner N, Bogstad B, Mehl S (2001) Distribution of Themisto (Amphipoda) spp. in the Barents Sea and predator-prey interactions. ICES J Mar Sci 58:876-895

Dauble DD, Gray RH, Skalski JR, Lusty EW, Simmons MA (1985) Avoidance of a water-soluble fraction of coal liquid by fathead minnows. Trans Am Fish Soc 114:754-760

Dickson RR, Osborn TJ, Hurrell JW, Meincke J and 5 others (2000) The Arctic Ocean response to the North Atlantic oscillation. J Clim 13:2671-2696

Dingsør GE, Ciannelli L, Chan KS, Ottersen G, Stenseth NC (2007) Density dependence and density independence during the early life stages of 4 marine fish stocks. Ecology 88:625-634

Durant JM, Hjermann DØ, Ottersen G, Stenseth NC (2007) Climate and the match or mismatch between predator requirements and resource availability. Clim Res 33: 271-283

Eikeset AM, Dunlop E, Dieckmann U (2005) Fisheriesinduced evolution in Northeast Arctic cod. ICES CM 2005/AA:16

Ernande B, Dieckmann U, Heino M (2004) Adaptive changes in harvested populations: plasticity and evolution of age and size at maturation. Proc R Soc Lond Ser B 271:415-423

ExxonMobil (2004) ExxonMobil sets Valdez record straight. News Release October 6, 2004. (Retrieved from www. exxonmobil.com/ on March 23, 2007)

Farr AJ, Chabot CC, Taylor DH (1995) Behavioral avoidance of fluoranthene by fathead minnows (Pimephales promelas). Neurotoxicol Teratol 17:265-271

Fiksen O, Slotte A (2002) Stock-environment recruitment models for Norwegian spring spawning herring (Clupea harengus). Can J Fish Aquat Sci 59:211-217

Fossum I (2006) Analysis of instabilities and mesoscale motion off southern Norway. J Geophys Res 111:C08006, doi: 10.1029/2005JC003228

Fossum I, Røed LP (2006) Analysis of instabilities and mesoscale motion in continuously stratified ocean models. J Mar Res 64:319-353

Garrett RM, Rothenburger SJ, Prince RC (2003) Biodegradation of fuel oil under laboratory and Arctic marine conditions. Spill Science Technol Bull 8:297-302

Gjøsæter H (1998) The population biology and exploitation of capelin (Mallotus villosus) in the Barents Sea. Sarsia 83: 453-496

Gjøsæter H, Bogstad B (1998) Effects of the presence of herring (Clupea harengus) on the stock-recruitment relationship of Barents Sea capelin (Mallotus villosus). Fish Res 38:57-71

Gjøsæter H, Loeng H (1987) Growth of the Barents Sea capelin, Mallotus Villosus, in relation to climate. Environ Biol Fish 20:293-300

Gjøsæter H, Dommasnes A, Rottingen B (1998) The Barents Sea capelin stock 1972-1997. A synthesis of results from acoustic surveys. Sarsia 83:497-510

Gjøsæter H, Dalpadado P, Hassel A (2002) Growth of Barents
Sea capelin (Mallotus villosus) in relation to zooplankton abundance. ICES J Mar Sci 59:959-967

Hamre J (1994) Biodiversity and exploitation of the main fish stocks in the Norwegian-Barents Sea ecosystem. Biodivers Conserv 3:473-492

Hamre J (2003) Capelin and herring as key species for the yield of north-east Arctic cod. Results from multispecies model runs. Scient Mar 67 (Suppl. 1):315-323

Hassel A, Skjoldal HR, Gjøsæter H, Loeng H, Omli L (1991) Impact of grazing from Capelin (Mallotus villosus) on zooplankton-a case-study in the northern Barents Sea in August 1985. Polar Res 10:371-388

Haug T, Nilssen KT (1995) Ecological implications of harp seal Phoca groenlandica invasions in northern Norway. In: Blix AS, Walløe L, Ulltang O (eds) Whales, seals, fish and man, Vol 4. Elsevier, Amsterdam, p 545-556

Heino M, Godø OR (2002) Fisheries-induced selection pressures in the context of sustainable fisheries. Bull Mar Sci 70:639-656

Heino M, Dieckmann U, Godø OR (2002a) Measuring probabilistic reaction norms for age and size at maturation. Evolution 56:669-678

Heino M, Dieckmann U, Godø OR (2002b) Reaction norm analysis of fishery-induced adaptive change and the case of the Northeast Arctic cod. ICES CM Y:14

Heintz RA, Rice SD, Wertheimer AC, Bradshaw RF, Thrower FP, Joyce JE, Short JW (2000) Delayed effects on growth and marine survival of pink salmon Oncorhynchus gorbuscha after exposure to crude oil during embryonic development. Mar Ecol Prog Ser 208:205-216

Helland-Hansen B, Nansen F (1909) The Norwegian Sea: Its physical oceanography based upon the Norwegian research 1900-1904, Part 1, No. 2. Fiskeridir Skr Ser Havunders 3

Hellstrøm T, Døving KB (1983) Perception of diesel oil by cod (Gadus morhua L.). Aquat Toxicol 4:303-315

Hillebrand H (2004) Strength, slope and variability of marine latitudinal gradients. Mar Ecol Prog Ser 273:251-267

Hjermann DØ, Stenseth NC, Ottersen G (2004a) The population dynamics of northeast Arctic cod through two decades: an analysis based on survey data. Can J Fish Aquat Sci 61:1747-1755

Hjermann DØ, Stenseth NC, Ottersen G (2004b) Indirect climatic forcing of the Barents Sea capelin: a cohort-effect. Mar Ecol Prog Ser 273:229-238

Hjermann DØ, Ottersen G, Stenseth NC (2004c) Competition among fishermen and fish causes the collapse of Barents Sea capelin. Proc Natl Acad Sci USA 101:11679-11684

Hjermann DØ, Bogstad B, Eikeset AM, Ottersen G, Gjøsæter H, Stenseth NC (2007) Food web dynamics affect NorthEast Arctic cod recruitment. Proc R Soc Lond Ser B 274: 661-669

Hjort J (1914) Fluctuations in the great fisheries of northern Europe viewed in the light of biological research. Rapp P-V Réun Cons Int Explor Mer 20:1-228

Hose JE, McGurk D, Marty GD, Hinton DE, Brown ED, Baker TT (1996) Sublethal effects of the Exxon Valdez oil spill on herring embryos and larvae: Morphological, cytogenetic, and histopathological assessments, 1989-1991. Can J Fish Aquat Sci 53:2355-2365

Hurrell JW, Kushnir Y, Ottersen G, Visbeck M (eds) (2003) The North Atlantic Oscillation: climate significance and environmental impact, Vol 134. American Geophysical Union, Washington, DC

ICES (2005) Report of the Arctic Fisheries Working Group. ICES CM 2005/ACFM:20

Incardona JP, Collier TK, Scholz NL (2004) Defects in cardiac 
function precede morphological abnormalities in fish embryos exposed to polycyclic aromatic hydrocarbons. Toxicol Appl Pharmacol 196:191-205

Ingvaldsen R, Loeng H, Ottersen G, Ådlandsvik B (2003) Climate variability in the Barents Sea during the 20th century with a focus on the 1990s. ICES Mar Sci Symp 219: 160-168

IPIECA (1997) Biological impacts of oil pollution: fisheries. IPIECA Rep Ser 8, International Petroleum Industry Environmental Conversation Association, London

ITOPF (2002) Fate of marine oil spills. Tech Info Pap, International Tanker Owners Pollution Federation, London

Johansen Ø, Skognes K, Aspholm OØ, Østby C, Moe KA, Fossum P (2003) Uhellsutslipp av olje-konsekvenser i vannsøylen (ULB 7-c). Foundation for Scientific and Industrial Research at the Norwegian Institute of Technology (SINTEF), Trondheim

Kjesbu OS, Kryvi H, Sundby S, Solemdal P (1992) Buoyancy variations in eggs of Atlantic cod (Gadus morhua L.) in relation to chorion thickness and egg size-theory and observations. J Fish Biol 41:581-599

Kjesbu OS, Solemdal P, Bratland P, Fonn M (1996) Variation in annual egg production in individual captive Atlantic cod (Gadus morhua). Can J Fish Aquat Sci 53: $610-620$

Kjesbu OS, Witthames PR, Solemdal P, Walker MG (1998) Temporal variations in the fecundity of Arcto-Norwegian cod (Gadus morhua) in response to natural changes in food and temperature. J Sea Res 40:303-321

Loeng H (1991) Features of the physical oceanographic conditions of the Barents Sea. Polar Res 10:5-18

Marshall CT, Kjesbu OS, Yaragina NA, Solemdal P, Ulltang O (1998) Is spawner biomass a sensitive measure of the reproductive and recruitment potential of Northeast Arctic cod? Can J Fish Aquat Sci 55:1766-1783

Marshall CT, Yaragina NA, Lambert Y, Kjesbu OS (1999) Total lipid energy as a proxy for total egg production by fish stocks. Nature 402:288-290

Martinsen EA (1982) Operational oil drift model for Norwegian waters and surrounding oceans. Tech Rep 59, Norwegian Meteorological Institute, Oslo (in Norwegian)

Martinsen EA, Melsom A, Sveen V, Grong E, Reistad M, Halvorsen N, Johansen $\varnothing$, Skognes K (1994) The operational oil drift system at DNMI. Tech Rep 125, Norwegian Meteorological Institute, Oslo

Mehl S (2004) Abundance of spawning Northeast Arctic cod spring 2004. Toktrapport Nr. 9-2004, Institute of Marine Research, Bergen, Norway

Mehl S, Nedreaas K (2003) Abundance of spawning Northeast Arctic cod spring 2003, Toktrapport Nr. 13-2003, Institute of Marine Research, Bergen, Norway

Melsom A (2005) Mesoscale activity in the North Sea as seen in ensemble simulations. Ocean Dyn 55:338-350

Melsom A, Metzger EJ, Hurlburt HE (2003) Impact of remote oceanic forcing on Gulf of Alaska sea levels and mesoscale circulation. J Geophys Res Oceans 108:C113346, doi:10. 1029/2002JC001742

Metzger EJ, Hurlburt HE (2001) The nondeterministic nature of Kuroshio penetration and eddy shedding in the South China Sea. J Phys Oceanogr 31:1712-1732

National Research Council (1985) Oil in the sea. III: Inputs, fates and effects. National Academies Press, Washington, $\mathrm{DC}$

Olsen EM, Heino M, Lilly GR, Morgan MJ, Brattey J, Ernande B, Dieckmann U (2004) Maturation trends indicative of rapid evolution preceded the collapse of northern cod. Nature 428:932-935
Orvik KA, Niiler P (2002) Major pathways of Atlantic water in the northern North Atlantic and Nordic Seas toward Arctic. Geophys Res Lett 29:1896

Orvik KA, Skagseth O, Mork M (2001) Atlantic inflow to the Nordic Seas: current structure and volume fluxes from moored current meters, VM-ADCP and SeaSoar-CTD observations, 1995-1999. Deep-Sea Res I 48:937-957

Østerhus S, Hansen B (2000) North Atlantic-Norwegian Sea exchanges. Progr Oceanogr 45:109-208

Ottersen G, Planque B, Belgrano A, Post E, Reid PC, Stenseth NC (2001) Ecological effects of the North Atlantic Oscillation. Oecologia 128:1-14

Ottersen G, Hjermann D, Stenseth NC (2006) Changes in spawning stock structure strengthens the link between climate and recruitment in a heavily fished cod stock. Fish Oceanogr 15:230-243

Paine RT (1980) Food webs - linkage, interaction strength and community infrastructure. The 3rd Tansley Lecture. J Anim Ecol 49:667-685

Paine RT, Ruesink JL, Sun A, Soulanille EL, Wonham MJ, Harley CDG, Brumbaugh DR, Secord DL (1996) Trouble on oiled waters: lessons from the Exxon Valdez oil spill. Annu Rev Ecol Systs 27:197-235

Perkins RA, Rhoton S, Behr-Andres C (2005) Comparative marine toxicity testing: a cold-water species and standard warm-water test species exposed to crude oil and dispersant. Cold Regions Sci Technol 42:226-236

Peterson CH, Rice SD, Short JW, Esler D, Bodkin JL, Ballachey BE, Irons DB (2003) Long-term ecosystem response to the Exxon Valdez oil spill. Science 302:2082-2086

Reznick DN, Ghalambor CK (2005) Can commercial fishing cause evolution? Answers from guppies. Can J Fish Aquat Sci 62:791-801

Reznick DN, Rodd FH, Cardenas M (1996) Life-history evolution in guppies (Poecilia reticulata: Poeciliidae).4. Parallelism in life-history phenotypes. Am Nat 147:319-338

Rijnsdorp AD, Grift RE, Kraak SBM (2005) Fisheries-induced adaptive change in reproductive investment in North Sea plaice (Pleuronectes platessa)? Can J Fish Aquat Sci 62: 833-843

Rudberg A (2003a) Oljedriftsmodellering i Lofoten og Barentshavet. Spredning av olje ved akutte utslipp. ULB delutredning 7-a. DNV rapport nr. 2003-0385, Det Norske Veritas, Høvik

Rudberg A (2003b) Oljedriftsmodellering i Lofoten og Barentshavet; spredning av olje ved akutte utslipp til sjø. ULB Delutredning 7-a, Det Norske Veritas, Høvik

Sætre R, Mork M (1981) The Norwegian Coastal Current, Vol 1 \& 2. Proc Norwegian Coastal Current Symp, University of Bergen, Bergen, Norway

Salthaug A (2002) Revidert rapport fra tokt med F/F G.O. Sars, Lofoten 16.03.-02.04.02. Toktrapport Nr. 34-2002, Institute of Marine Research, Bergen

Scott GR, Sloman KA (2004) The effects of environmental pollutants on complex fish behaviour: integrating behavioural and physiological indicators of toxicity. Aquat Toxicol 68:369-392

Stenseth NC, Mysterud A, Ottersen G, Hurrell JW, Chan KS, Lima M (2002) Ecological effects of climate fluctuations. Science 297:1292-1296

Stenseth NC, Ottersen G, Hurrell JW, Mysterud A, Lima M, Chan KS, Yoccoz NG, Adlandsvik B (2003) Studying climate effects on ecology through the use of climate indices: the North Atlantic Oscillation, El Niño-Southern Oscillation and beyond. Proc R Soc Lond Ser B 270: 2087-2096

Tjelmeland S, Bogstad B (1998) MULTSPEC - a review of a 
multispecies modelling project for the Barents Sea. Fish Res 37:127-142

USGS (2000) World petroleum assessment 2000—Description and results, US Geological Survey, Reston, VA

Webster L, Angus L, Topping G, Dalgarno EJ, Moffat CF (1997) Long-term monitoring of polycyclic aromatic hydrocarbons in mussels (Mytilus edulis) following the Braer oil spill. Analyst 122:1491-1495

Webster L, McIntosh AD, Moffat CF, Dalgarno EJ, Brown NA, Fryer RJ (2000) Analysis of sediments from Shetland Island voes for polycyclic aromatic hydrocarbons, steranes and triterpanes. J Environ Monitor 2:29-38

Webster L, Fryer RJ, Dalgarno EJ, Megginson C, Moffat CF (2001) The polycyclic aromatic hydrocarbon and geo-

Editorial responsibility: Howard Browman (Associate Editorin-Chief), Storebø, Norway chemical biomarker composition of sediments from voes and coastal areas in the Shetland and Orkney Islands. J Environ Monitor 3:591-601

Wettre C, Johansen $\varnothing$, Skognes K (2001) Development of a 3-dimensional oil drift model at DNMI. Res Rep No. 133, Norwegian Meteorological Institute, Oslo

Wolfe DA, Hameedi MJ, Galt JA, Watabayashi G and 8 others (1994) The fate of the oil spilled from the Exxon Valdez. Environ Sci Technol 28:A560-A568

Worm B, Myers RA (2003) Meta-analysis of cod-shrimp interactions reveals top-down control in oceanic food webs. Ecology 84:162-173

Zenkevitch LA (1963) Biology of the seas of the USSR. Allan and Unwin, London

Submitted: June 11, 2006; Accepted: October 10, 2006 Proofs received from author(s): May 3, 2007 